\title{
Effect of Handling, Milling Process and Storage on the Quality of Wheat and Flour in Egypt: [3] Sensory Evaluation for Bread Making from Different Wheat Flours
}

\author{
El-Sisy TT ${ }^{2 *}$, Abd El Fadel MG ${ }^{1}$, Gad SS ${ }^{1}$, El-Shibiny AA $^{1}$ and Emara MF ${ }^{2}$ \\ ${ }^{1}$ Faculty of Environmental Agricultural Science (Arish), Suez Canal University, Egypt \\ ${ }^{2}$ Regional Center for Food and Feed, Agriculture Research Central, Egypt \\ *Corresponding Author: PEl-Sisy TT, Regional Center for Food and Feed, Agriculture Research Central, Egypt.
}

Received: August 28, 2019; Published: September 30, 2019

\begin{abstract}
Five imported wheat kernels (Australian, Argentine, Ukrainian, American and Germany), and local wheat cultivars Egyptian wheat (Gamaza7) were subjected to bread quality evaluation. Result, indicated that the Germany wheat grains had higher total physical defects. Flour yields were about $70 \%$ for all tested wheat samples except for the American soft red winter wheat and Ukrainian hard red wheat, which were as low as $65.0 \%$. A wide range of protein content ( $9.60-11.50 \%)$ of flours was recorded. The Argentine soft red winter wheat flour had the highest protein content and the Australian stander white wheat flour was the lowest in protein content. Wet and dry gluten contents of wheat flour samples were consistent with their protein contents. Rheological evaluation data indicated that Australian and Argentine, flours had more suitable properties for bread- making than the American and Egyptian flours. Quality evaluation of the manufactured bread samples from the different tested wheat flours indicated that those made from Australian wheat, and Argentine wheat flours were superior.
\end{abstract}

Keywords: PWheat; Flour; Handling; Milling; Storage; Bread; Quality Evaluation

\section{Introduction}

Most wheat varieties presently cultivated are grouped under the broad category of common or bread wheat' (Triticum aestivum), which accounts for approximately 95\% of world production, and durum wheat (Triticum durum) used for pasta production [1]. In Egypt, 10.9 million tons of different wheat varieties are milled per year (2003 data). Millers buy wheat with a wide range of quality characteristics. About 4057234 tons (37.2\%) of imported wheats and 6844692 tons (62.8\%) of local wheats were used during the season of 2003 [2]. Most of these amounts are used for bread making, while the rest are used for other baked products and pasta production. The durum wheats are grown commercially in drier regions of the country, for example, the brown soil zone of the central Prairies in Canada. They are characterized by having large, ovate-shaped, ambercoloured kernels that are very hard, almost flinty in texture. This class of wheats is used exclusively for pasta products throughout the world, as well as for other specialty products, such as cous-cous, in some countries. The bread wheats encompass a wide range of different types classified largely by their growth habit and functionality. The various classes are combinations of winter or spring growth habit with white or red kernels and hard- or soft-textured kernels. For example, both spring and winter wheats include types with hard or soft and red or white kernels. Bread is baked from the flour of varieties with hard kernels, predominantly the red type. They have a high protein content and high levels of predominantly two protein frac- tions, gliadins and glutenins. These impart elasticity to the dough during baking so that large loaves of bread can be produced. The soft wheats typically have lower protein contents and lower levels of the two critical protein fractions. They are used in unleavened bakery products like pastries and breakfast cereals: indeed, white soft wheat flour is preferred for breakfast cereal processing. Many different types and strains of wheat are grown conventionally or organically worldwide. In the United States wheat is classified into four categories. Hard wheat is used for breads and similar baked goods; soft wheat is preferred for cakes and pastries; winter wheat, which includes hard wheat varieties, is planted in the late fall to over-winter in harsh climates and is harvested in the spring; and spring wheat is planted in the spring and is harvested in the late summer or early fall. Wheat is further categorized as red wheat, that is, hard, red winter wheat; or white wheat, that is, soft, white spring wheat. The baker's knowledge of the specific flour's profile dictates how much water to add, how long to knead the dough, and how long the fermentation time should be. Identity preserved (IP) wheat has also attracted interest. Franklin [3]. Grain yield and quality of a crop variety is the end result of interactions between the variety and the environment. Wheat quality depends upon the genetic factors but environmental. conditions, growth locations; agronomic practices prevailing during different wheat growth stages greatly alter the wheat quality attributes. Generally wheat quality refers to its suitability for a particular end-use based on physical, chemical and nutritional properties of wheat grain. Protein content 
is a key quality factor that determines the suitability of wheat for a particular type of product as it affects other factors including mixing tolerance, loaf volume and water absorption capacity [4]. Wheat flour is the major ingredient in many products and consequently it exerts a major effect on their quality. It is also a complex biological entity and, as such, varies significantly with the source of the wheat. As a complex system, and because it is obtained from a plant, wheat flour contains a multitude of compounds found in any living tissue. The most of these components play an important role in the way of how the flour-based and other product constituens will behave during processing or how the final product meets the consumer's requirements Katarina and Dušanka [5]. The flour yield and flour properties, among other things, are strongly related to wheat kernel properties, especially to the mechanical properties. Beside the mechanical properties, also others, such as kernel colour, vitreousness, mass, shape, test weight, density, size and size uniformity, are taken into consideration during wheat milling value evaluation. These properties depend on many factors, such as genetic heritage, agro-technical methods or agroenvironmental conditions. On the basis on these properties we can also conclude about the end use of wheat. Studies concerning the relations between the wheat kernel physical properties and the milling properties have been carried out since the beginning of the cereal processing industry [6]. Bread-making quality of a variety usually reacts like other quantitative characteristics to favourable or unfavourable environmental conditions and varies its performance. It is unrealistic to expect the same level of performance in all environments [7]. For the milling and baking industry, it is desirable that quality traits should be maintained as stable as possible through all environments. There exit different concepts of stability definition. The rheological characteristics of the dough are usually studied using the farinograph and mixograph. In general, the farinograph stability time is affected by material flour wet gluten, protein content, protein compositions, the type of high molecular weight glutenin subunits (HMW-GS), and so on. In addition, it is significantly correlated with the processing quality such as bread making and steamed bread making, indicating that the dough stability time is one of the important quality indexes for classifying wheat and determining their end use. It is known that the stability time of bread-making flour was determined to be $12 \pm 1.5 \mathrm{~min}$ in some countries such as USA and Canada. According to GB/T179821999 of China (The State Administrition of Grain Reserve, Ministry of Agriculture of China 1999), the stability time of the first-class strong gluten wheat is longer than or equal to $10 \mathrm{~min}$; and wheats having stability time longer than or equal to $7 \mathrm{~min}$ were considered to be second-class strong gluten, whereas wheat having stability time shorter than 1.5 min were considered to be weak gluten wheat [8].

The aim of research to evaluate the most common imported wheats (Australian, Argentine, Ukrainian, American and Germany), as well as a local wheat cultivars Egyptian wheat (Gamaza7) for bread - making. -The physical, chemical, rheological as well as the manufactured bread quality characteristics were examined.

\section{Materials and Methods}

Wheat samples

Five imported wheat grains (Triticum aestivum) different cultivars were obtained from Argentin, Germany, Ukrainian, Australia and U.S.A which were obtained from five locations (Alexandria, Domiata, El-Suwas, El-Skhna and Cairo) and Egyptian wheat grains (gamaza 7) were obtained from El-Ghrbia. They were taken from six different Companies since 2009.

\section{Preparation of wheat flours}

A twenty $\mathrm{kg}$ of each wheat sample used in this investigation was stored 90 days at temperature $25^{\circ} \mathrm{c}$ and relative humidity less than $62 \%$ and taken samples from stored wheat at different time $(0,7,14,21,30,36,42,49,60,66,72,84$ and 90) According to the methods described in U.S. Department of Agriculture [9]. At the end of stored wheat sample was cleaned mechanically to remove dirt, dockage, imparters and other strange grains by Carter Dockage Tester According to the methods described in U.S. Department of Agriculture [10,11]. the wheat samples were tempered to $16.5 \%$ moisture and allowed to conditioning for 24 hours, than milled by Laboratory mill CD1 auto Chopin According to the methods described in AACC method [12]. The extraction rate of flour sample was adjusted to recurred rate ( 72 and $82 \%$ extraction).

\section{Bread processing}

Different samples of flours were used to produce standard toast and balady breads according to the formula showed in table 1 .

\begin{tabular}{|l|c|c|c|c|c|}
\hline $\begin{array}{c}\text { Type of } \\
\text { bread }\end{array}$ & Flour & Moisture & Yeast & Salt & Sugar \\
\hline $\begin{array}{l}\text { Stander } \\
\text { Toast }\end{array}$ & $1000 \mathrm{gm}$ & $14 \%$ & $20 \mathrm{gm}$ & Nacl 10gm & $\begin{array}{c}\text { Sucrose } \\
10 \mathrm{gm}\end{array}$ \\
\hline Balady & $1000 \mathrm{gm}$ & $14 \%$ & $20 \mathrm{gm}$ & Nacl 5gm & non \\
\hline
\end{tabular}

Table 1

\section{Standard toast}

Standard Toast was prepared According to the methods described in AACC method [12]. All ingradined of Stander Toast (shown in Table 1) were mixed with water to Farinograph Chopin test. The dough was mixed for 5-10 min. until the correct consistency was obtained. Dough fermentation and branding of the dough for $7 \mathrm{~min}$. dough were divided to $300 \mathrm{gm}$ and put in pan no. 17 which fermentation for 2 hours at $30^{\circ} \mathrm{c}$ and relative humidity $80 \%$. All samples were baked at $230^{\circ} \mathrm{C}$ for $20 \mathrm{~min}$. at electric oven (Futurci oven 220 Perten) in Regional Center for Food and Feed, Agri. Res. Center, Cairo, Egypt.

\section{Balady bread}

Wheat flour (82\% extraction) was baked into Balady bread loaves using straight dough methods Rashaed et al. [13]. Balady formula consists shown in table 1 . The ingradined were mixed for 20 min. after mixed with water according to Farinograph Chopin test by using Mixer gostol-gopan Perten and then the dough was left for $30 \mathrm{~min}$, dough was divided in to $150 \mathrm{gm}$. Pieces that were arranged on a wooden board previously sprinkled with fine layer of 
bran and kept for $20 \mathrm{~min}$ at $30^{\circ} \mathrm{c}$ and $85 \%$ relative humindty. The pieces were flattened to about $20 \mathrm{~cm}$ diameter proofed at $30^{\circ} \mathrm{C}$ and $85 \%$ relative humidity for $30 \mathrm{~min}$. and then baked at $400-500^{\circ} \mathrm{C}$ for 1-2 min. in a pilot oven in Regional Center for Food and Feed, Agri. Res. Center, Cairo, Egypt.

\section{Baking mixture}

All samples of wheat flour were used to produce balady (82\% extraction) and standard toast ( $72 \%$ extraction) bread only. For addition each sample of Egyptian flour were mixed with different kind of flour produce from imported wheat by two percentage $(25$, $50 \%$ ) to produce 20 mixtures.

\section{Sensory evaluation}

Standard toast

Stander toast bread loaves were orgaolpticaly evaluated According to the method described in AACC method [12]. The fresh sample was delivered to 100 panelists 2 hours after baking.

\section{Balady bread}

Balady bread loaves were organoleptically evaluated According to the method described in AACC method [12]. The fresh sample was delivered to 100 panelists 2 hours after baking.

\section{Statistical analysis}

Data of three replicates were computed for the analysis of standard division (S.D) among the means were determined by Duncan's multiple range test using SAS programs [14].

\section{Results and Discussion}

Physical properties of Toast and Balady bread made from different wheat flour (100\%) and mixing by 75 and $50 \%$ with Egyptian wheat flour

\section{Standard toast}

The obtained results showed that the different values were observed on all physical properties of toast making such as crust colour, weight after baking, volume, specific volume and loaf volume. For crust colour showed that different colour between white and yellow which ranged from (-33.81 to -39.80) for the whiteness and (55.30 to 65.10) for yellowness, Egyptian toast had the shine golden yellow colour 65.1 while Ukrainian toast had less yellow colour 55.3 on the other hand the American toast had golden red colour 69.7 which is not good ability to panelists. Additionally table 2 presented that the weight after baking for among of toast were ranged from 255 to 275 gm Argentine toast had heaviest weight 275gm while Egyptian, American and Australian toast had lightest weight 255, 255 and 256 respectively. In the other side the volume after baking is different because the Australian toast had highest volume $1050 \mathrm{~cm} 3$ followed by Argentine toast $1000 \mathrm{~cm}^{3}$ while Egyptian toast had lowest volume $569 \mathrm{~cm}^{3}$. So the specific volume is related to the volume too because the Australian toast had highest volume $4.1 \mathrm{~cm}^{3} / \mathrm{g}$ followed by Argentine toast 3.63 $\mathrm{cm}^{3} / \mathrm{g}$ while Egyptian toast had lowest volume $2.23 \mathrm{~cm}^{3} / \mathrm{g}$, however loaf volume for Australian toast had lowest loaf volume $0.24 \mathrm{~g} /$ $\mathrm{cm}^{3}$ and more cells of air followed by Argentine toast $0.28 \mathrm{~g} / \mathrm{cm}^{3}$ while Egyptian toast had highest loaf volume $0.94 \mathrm{~g} / \mathrm{cm}^{3}$ and less cells of air. More ever data of baking mixing flour (75\% Egyptian flour and $25 \%$ other flour) showed that Argentine toast had the shine golden yellow colour 64.2 while Ukrainian toast had less yellow colour (60.2). Table 1 presented that the weight after baking for among of toast were ranged between 279 to 281gm, Ukrainian toast had heaviest weight 281gm followed by Germany and Australian toast bread 280gm while Argentine and American toast had lightest weight $279 \mathrm{gm}$, in the other side the volume after baking is different because the Argentine toast had highest volume $850 \mathrm{~cm} 3$ followed by Australian toast bread $830 \mathrm{~cm} 3$ while American toast had lowest volume $780 \mathrm{~cm} 3$, forever the specific volume is related to the volume too because the Argentine toast bread had highest volume $3.05 \mathrm{~cm} 3 / \mathrm{g}$ while American, toast bread had lowest volume $2.79 \mathrm{~cm} 3 / \mathrm{g}$, however loaves volume for Argentine toast had lowest loaf volume $0.33 \mathrm{~g} / \mathrm{cm}^{3}$ and more cells of air while Germany toast bread had highest loaf volume $0.34 \mathrm{~g} / \mathrm{cm}^{3}$ and less cells of air. On the other hand data of toast making from mixing flour (50\% Egyptian flour and 50\% other flour) showed that Argentine toast had the shiniest golden yellow colour 65.0 while American toast had less yellow colour (55.8). From the same Table it can be observed that the weight after baking for among of toast were ranged between 256 to $264 \mathrm{gm}$ so Ukrainian toast bread had heaviest weight 264gm while Germany toast had lightest weight 256gm. In the other side the volume after baking was different because the Argentine toast had highest volume $1100 \mathrm{~cm}^{3}$ followed by Australian toast $1065 \mathrm{~cm}^{3}$ while American toast had lowest volume $990 \mathrm{~cm}^{3}$, so the specific volume was related to the volume too because the Argentine toast had highest volume $4.21 \mathrm{~cm}^{3} / \mathrm{g}$ followed by Australian toast $4.08 \mathrm{~cm}^{3} / \mathrm{g}$ while American toast had lowest volume $3.75 \mathrm{~cm}^{3} / \mathrm{g}$, however loaf volume for Argentine toast had lowest loaf volume $0.23 \mathrm{~g} / \mathrm{cm}^{3}$ and more cells of air followed by Australian toast $0.24 \mathrm{~g} / \mathrm{cm}^{3}$ while American toast had highest loaf volume $0.27 \mathrm{~g} / \mathrm{cm}^{3}$ and less cells of air.

Data of baking pure flour $100 \%$ (control) presented in table 3 It can be observed that crumb of toast bread ranged between 47.5 to $55.5 \%$, inner crust ranged between 36.4 to $43.1 \%$ and out crust ranged between 4.5 to 9.4 for bread fraction percentage of total fresh weight. Argentine, Germany and Egyptian toast had highest value of crumb 55.0, 55.5 and 55.5\% respectively while Australian toast had lowest value $47.5 \%$. on the other hand inner crust for Egyptian toast is lightest value 36.4 and out crust of Argentine toast had lightest value $4.5 \%$ while American toast had thickness value for inner and out crust $43.1 \%$ and $9.4 \%$ respectively. However data of baking mixing flour (75\% Egyptian flour and $25 \%$ other flour) showed in table 3 that bread fraction percentage of toast fresh weight for crumb which ranged between 53.4 to $55.5 \%$, Germany toast had highest value of crumb 55.5\% followed by Argentine toast 55.3\% while American toast had lowest value of crumb $53.4 \%$. On the other hand inner crust for Germany toast is lightest value 40.9 and out crust of Ukrainian toast had lightest value $3.4 \%$ while American toast had thickness value for inner and out crust $42.7 \%$ and $3.9 \%$ respectively. On the other hand data of Baking mixing flour (50\% Egyptian flour and 50\% of other flour) present- 


\begin{tabular}{|c|c|c|c|c|c|c|c|}
\hline \multirow{2}{*}{\multicolumn{2}{|c|}{ Wheat Flour }} & \multicolumn{2}{|c|}{ Crust colour } & \multirow{3}{*}{$\begin{array}{c}\text { Weight after } \\
\text { baking gm }\end{array}$} & \multirow{3}{*}{$\begin{array}{c}\begin{array}{c}\text { Volume after } \\
\text { baking gm }\end{array} \\
1000\end{array}$} & \multirow{3}{*}{$\begin{array}{c}\begin{array}{c}\text { Specific volume } \\
\mathbf{c m}^{3} / \mathbf{g}\end{array} \\
3.63 \\
\end{array}$} & \multirow{3}{*}{$\begin{array}{c}\begin{array}{c}\text { Loaf volume } \\
\mathbf{c m}^{3}\end{array} \\
0.28 \\
\end{array}$} \\
\hline & & \multirow{2}{*}{$\begin{array}{l}\text { White } \\
-36.75\end{array}$} & \multirow{2}{*}{$\begin{array}{l}\text { Yellow } \\
62.00 \\
\end{array}$} & & & & \\
\hline Control 100\% & ArW & & & & & & \\
\hline & GeW & -36.50 & 60.10 & 260 & 850 & 3.27 & 0.30 \\
\hline & UkW & -33.81 & 55.30 & 256 & 840 & 3.28 & 0.31 \\
\hline & $\mathrm{AmW}$ & -39.80 & 69.70 & 255 & 600 & 2.35 & 0.43 \\
\hline & $\mathrm{AuW}$ & -37.91 & 63.30 & 256 & 1050 & 4.10 & 0.24 \\
\hline & ESW & -38.70 & 65.10 & 255 & 569 & 2.23 & 0.94 \\
\hline $25 \%+75 \%$ & ArW & -39.25 & 64.20 & 279 & 850 & 3.05 & 0.33 \\
\hline & GeW & -38.27 & 62.60 & 280 & 800 & 2.85 & 0.35 \\
\hline & UkW & -36.81 & 60.20 & 281 & 790 & 2.81 & 0.36 \\
\hline & $\mathrm{AmW}$ & -38.15 & 62.40 & 279 & 780 & 2.79 & 0.36 \\
\hline & $\mathrm{AuW}$ & -38.86 & 63.55 & 280 & 830 & 2.96 & 0.33 \\
\hline $50 \%+50 \%$ & ArW & -39.74 & 65.00 & 261 & 1100 & 4.21 & 0.23 \\
\hline & GeW & -37.97 & 62.10 & 256 & 1055 & 4.12 & 0.24 \\
\hline & UkW & -36.44 & 59.60 & 263 & 1030 & 3.91 & 0.26 \\
\hline & $\mathrm{AmW}$ & -34.12 & 55.80 & 264 & 990 & 3.75 & 0.27 \\
\hline & $\mathrm{AuW}$ & -36.75 & 60.10 & 261 & 1065 & 4.08 & 0.24 \\
\hline
\end{tabular}

Table 2: Physical properties of Toast made from different wheat flour (100\%) and mixing by 75 and 50\% with Egyptian wheat flour. 1.0h: 1.0 hour fermentation; 1.5h: 1.5 hour fermentation; 2.0h: 2.0 hour fermentation; ArW: Argentine Soft Red winter Wheat; GeW: Germany Soft Red Wheat, UkW Ukrainian Hard Red Wheat; AmW: American Soft Red Winter Wheat; AuW: Australian Stander White Wheat; ESW: Egyptian soft White Wheat (gamaza 7).

ed in table 3. Result showed that the bread fraction percentage of toast fresh weight for crumb which ranged between 50.5 to $55.5 \%$, inner crust ranged between 36.6 to $42.4 \%$ and out crust ranged between 6.7 to $7.9 \%$. Germany toast had a highest value of crumb $55.5 \%$, lightest value for inner crust $33.6 \%$ and thickness value for out crust $7.9 \%$ followed by Argentine toast $55.0 \%$ for crumb and $37.9 \%$ for inner crust while American toast had lowest value of crumb $50.5 \%$. and thickness value for out crust $42.4 \%$ while Ukrainian toast had lightest value of out crust $6.7 \%$ followed by Argentine and American toast. The incorporation of gluten bread baking quality of Argentine soft red winter wheat flour and Australian stander white wheat flour are presented in table 3 . The baking time increased with addition of gluten. Increase in baking percent, decrease in mixing time (2.5) and (3.0)min respectively. Crust and crumb colour increased with Egyptian soft White wheat variety. From this Tables 2,3 it can be concluded that the Argentine toast was the best Toast making from different wheat flour (100\%) and mixing by 75 and $50 \%$ with Egyptian wheat flour.

Results of Sensory evaluation of toast which made from different wheat flour (100\%) are shown in table 4. From obtained results it can be noticed that the Statistical analysis for total score was significantly differences between all toast making from different cultivars which ranged from 61.6 to 85.4, the Australian toast had highest total scores than the Egyptian and Argentine toast 85.4, 80.6 and $73.8 \%$ respectively until the lowest one is Germany toast $61.6 \%$. The Statistical analysis for crust colour was significantly differences between all toast making from different cultivars which ranged from 4.2 to 7.8. Highest mean score for crust colour (7.80) was obtained by Australian toast whereas Germany and american

\begin{tabular}{|c|c|c|c|c|}
\hline \multirow{2}{*}{\multicolumn{2}{|c|}{ wheat Flour }} & \multicolumn{3}{|c|}{$\begin{array}{l}\text { Bread fraction percentage of total } \\
\text { fresh weight } \%\end{array}$} \\
\hline & & \multirow{2}{*}{$\begin{array}{c}\text { Crumb } \\
55.0\end{array}$} & \multirow{2}{*}{$\begin{array}{c}\text { Inner crust } \\
40.5\end{array}$} & \multirow{2}{*}{$\begin{array}{c}\text { Out crust } \\
4.5\end{array}$} \\
\hline \multirow{6}{*}{$\begin{array}{l}\text { Control } \\
100 \%\end{array}$} & \multirow{6}{*}{$\begin{array}{l}\text { ArW } \\
\text { GeW } \\
\text { UkW } \\
\text { AmW } \\
\text { AuW } \\
\text { ESW }\end{array}$} & & & \\
\hline & & 55.5 & 37.3 & 7.2 \\
\hline & & 54.5 & 37.9 & 8.1 \\
\hline & & 47.5 & 43.1 & 9.4 \\
\hline & & 53.1 & 39.2 & 7.7 \\
\hline & & 55.5 & 36.4 & 8.1 \\
\hline \multirow[t]{5}{*}{$25 \%+75 \%$} & \multirow{5}{*}{$\begin{array}{l}\text { ArW } \\
\text { GeW } \\
\text { UkW } \\
\text { AmW } \\
\text { AuW }\end{array}$} & 55.3 & 40.9 & 3.8 \\
\hline & & 55.5 & 40.9 & 3.6 \\
\hline & & 55.2 & 41.4 & 3.4 \\
\hline & & 53.4 & 42.7 & 3.9 \\
\hline & & 55.0 & 41.4 & 3.6 \\
\hline \multirow[t]{5}{*}{$50 \%+50 \%$} & \multirow{5}{*}{$\begin{array}{c}\text { ArW } \\
\text { GeW } \\
\text { UkW } \\
\text { AmW } \\
\text { AuW }\end{array}$} & 55.0 & 37.9 & 7.1 \\
\hline & & 55.5 & 36.6 & 7.9 \\
\hline & & 54.5 & 38.8 & 6.7 \\
\hline & & 50.5 & 42.4 & 7.1 \\
\hline & & 53.6 & 39.1 & 7.3 \\
\hline
\end{tabular}

Table 3: Bread fraction of Toast made from different wheat flour (100\%) and mixing by 75 and 50\% with Egyptian wheat flour.

1.0h: 1.0 hour fermentation; $1.5 \mathrm{~h}: 1.5$ hour fermentation; $2.0 \mathrm{~h}: 2.0$ hour fermentation; ArW: Argentine Soft Red winter Wheat; GeW: Germany Soft Red Wheat, UkW Ukrainian Hard Red Wheat; AmW: American Soft Red Winter Wheat; AuW: Australian Stander White Wheat; ESW: Egyptian soft White Wheat (gamaza 7). 
toast got the lowest score (4.20). The low score of Germany and american toast may be due to high ash content, which affect the crust colour of bread since consumers prefer creamy colour and not dark brown bread. For appearance, Australian toast was at the top (17.6) followed by Egyptian toast (16.6) and found to be least (13.6) for Germany toast. Maximum aroma score (8.60) was attained by Australian toast while Germany toast bread received the minimum score (4.0). For crumb texture, highest mean score (16.8) was obtained by Australian toast followed by Egyptian toast (16.6). As regards eating quality, Australian toast got the maximum score (18.4) and Germany toast obtained the minimum score (12.8). Germany toast obtained the least score (13.2) for crumb grain whereas Australian toast bread received the highest score (16.2). With respect to overall acceptability of bread, highest score (85.4) was obtained by Australian toast and thus regarded as more acceptable than other wheat flour while lowest score (61.6) was obtained by Germany toast bread thus considered least acceptable. This results are parley with the results obtained by Farooq., et al. [15] and Dhaliwal., et al. [16].
Results of Sensory evaluation of toast which made from mixing different wheat flour 25\% with 75\% Egyptian wheat flour are shown in table 5. From the result it can be noticed that Australian and Argentine toast had highest total scores 74.4 and $73.0 \%$ respectively and less than the Egyptian toast $100 \%$ (control) $80.6 \%$ while American toast had the lowest total scores $65.2 \%$. Highest mean score for crust colour (6.20) was obtained by Australian and Argentine toast whereas Germany and Ukrainian toast got the lowest score (5.80). The low score of Germany and Ukrainian toast may be due to high ash content, which affect the crust colour of bread since consumers prefer creamy colour and not dark brown bread. In case of appearance, Australian toast was at the top (15.8) followed by Argentine toast (15.4) and found to be least (13.8) for American toast. Maximum aroma score (6.4) was attained by Australian and Argentine toast while American toast received the minimum score (4.6). For crumb texture, highest mean score (15.2) was obtained by Australian toast followed by Argentine toast (15.0). As regards eating quality, Australian toast got the maximum score (15.8) and

\begin{tabular}{|c|c|c|c|c|c|c|c|c|}
\hline \multicolumn{2}{|c|}{ Flour wheat } & Appearance 20 & $\begin{array}{c}\text { Crumb } \\
\text { texture 20 }\end{array}$ & $\begin{array}{c}\text { Crumb } \\
\text { Grain 20 }\end{array}$ & $\begin{array}{c}\text { Crust } \\
\text { colour } 10\end{array}$ & Aroma 10 & $\begin{array}{c}\text { Eating } \\
\text { quality } 20\end{array}$ & $\begin{array}{c}\text { Total scores } \\
100\end{array}$ \\
\hline \multirow{6}{*}{$\begin{array}{l}\text { Control } \\
100 \%\end{array}$} & \multirow{6}{*}{$\begin{array}{l}\text { ArW } \\
\text { GeW } \\
\text { UkW } \\
\text { AmW } \\
\text { AuW } \\
\text { ESW }\end{array}$} & $15.6^{\mathrm{bc}}$ & $15.4^{\mathrm{bc}}$ & $14.4^{\mathrm{abc}}$ & $6.2^{\mathrm{b}}$ & $6.0^{c}$ & $16.2^{\mathrm{b}}$ & 73.8 \\
\hline & & $13.6^{\mathrm{d}}$ & $13.8^{\mathrm{d}}$ & $13.2^{\mathrm{c}}$ & $4.2^{\mathrm{c}}$ & $4.0^{\mathrm{e}}$ & $12.8^{\mathrm{c}}$ & 61.6 \\
\hline & & $14.8^{\mathrm{cd}}$ & $15.2^{\mathrm{bc}}$ & $14.2^{\mathrm{bc}}$ & $5.4^{\mathrm{b}}$ & $5.6^{\mathrm{cd}}$ & $15.8^{\mathrm{b}}$ & 71.0 \\
\hline & & $14.2^{\mathrm{d}}$ & $14.6^{\mathrm{cd}}$ & $13.8^{\mathrm{bc}}$ & $4.2^{\mathrm{c}}$ & $4.6^{\mathrm{de}}$ & $14.0^{c}$ & 65.4 \\
\hline & & $17.6^{\mathrm{a}}$ & $16.8^{\mathrm{a}}$ & $16.2^{\mathrm{a}}$ & $7.8^{\mathrm{a}}$ & $8.6^{\mathrm{a}}$ & $18.4^{\mathrm{a}}$ & 85.4 \\
\hline & & $16.6^{\mathrm{ab}}$ & $16.2^{\mathrm{ab}}$ & $15.6^{\mathrm{ab}}$ & $7.2^{\mathrm{a}}$ & $7.2^{\mathrm{b}}$ & $17.8^{\mathrm{a}}$ & 80.6 \\
\hline
\end{tabular}

Table 4: Sensory evaluation of toast which made from different wheat flour (100\%).

ArW: Argentine Soft Red winter Wheat; GeW: Germany Soft Red Wheat; UkW: Ukrainian Hard Red Wheat; AmW: American Soft Red Winter Wheat; AuW: Australian Stander White Wheat; ESW: Egyptian soft White Wheat (gamaza 7).

\begin{tabular}{|c|c|c|c|c|c|c|c|c|}
\hline \multicolumn{2}{|c|}{ Flour wheat } & Appearance 20 & $\begin{array}{c}\text { Crumb } \\
\text { texture 20 }\end{array}$ & $\begin{array}{c}\text { Crumb } \\
\text { Grain 20 }\end{array}$ & $\begin{array}{c}\text { Crust } \\
\text { colour } 10\end{array}$ & Aroma 10 & $\begin{array}{c}\text { Eating } \\
\text { quality20 }\end{array}$ & $\begin{array}{c}\text { Total scores } \\
100\end{array}$ \\
\hline \multirow[t]{5}{*}{$25 \%+75 \%$} & \multirow{5}{*}{$\begin{array}{l}\text { ArW } \\
\text { GeW } \\
\text { UkW } \\
\text { AmW } \\
\text { AuW }\end{array}$} & $15.4^{\mathrm{ab}}$ & $15.0^{\mathrm{a}}$ & $14.8^{\mathrm{a}}$ & $6.2^{\mathrm{a}}$ & $6.4^{\mathrm{a}}$ & $15.2^{\mathrm{a}}$ & 73.0 \\
\hline & & $14.8^{\mathrm{abc}}$ & $14.8^{\mathrm{a}}$ & $14.6^{\mathrm{a}}$ & $5.8^{\mathrm{a}}$ & $6.0^{\mathrm{a}}$ & $15.0^{\mathrm{ab}}$ & 71.0 \\
\hline & & $14.4^{\mathrm{bc}}$ & $14.4^{\mathrm{a}}$ & $14.6^{\mathrm{a}}$ & $5.8^{\mathrm{a}}$ & $6.0^{\mathrm{a}}$ & $15.0^{\mathrm{ab}}$ & 70.2 \\
\hline & & $13.8^{c}$ & $12.6^{\mathrm{b}}$ & $14.6^{\mathrm{a}}$ & $6.0^{\mathrm{a}}$ & $4.6^{\mathrm{b}}$ & $13.6^{\mathrm{b}}$ & 65.2 \\
\hline & & $15.8^{\mathrm{a}}$ & $15.2^{\mathrm{a}}$ & $15.0^{\mathrm{a}}$ & $6.2^{\mathrm{a}}$ & $6.4^{\mathrm{a}}$ & $15.8^{\mathrm{a}}$ & 74.4 \\
\hline \multicolumn{2}{|l|}{ ESW 100\% } & $16.6^{\mathrm{ab}}$ & $16.2^{\mathrm{ab}}$ & $15.6^{\mathrm{ab}}$ & $7.2^{\mathrm{a}}$ & $7.2^{\mathrm{b}}$ & $17.8^{\mathrm{a}}$ & 80.6 \\
\hline
\end{tabular}

Table 5: Sensory evaluation of toast which made from mixing different wheat flour 25\% with 75\% Egyptian wheat flour.

ArW: Argentine Soft Red winter Wheat; GeW: Germany Soft Red Wheat; UkW: Ukrainian Hard Red Wheat; AmW: American Soft Red Winter Wheat; AuW: Australian Stander White Wheat; ESW: Egyptian soft White Wheat (gamaza 7).

American toast obtained the minimum score (13.6). Germany, American and Ukrainian toast obtained the least score (14.6) for crumb grain whereas Australian toast received the highest score (15.0). With respect to overall acceptability of bread, highest score (74.4) was obtained by Australian toast and thus regarded as more acceptable than other wheat flour while lowest score (65.2) was obtained by American toast thus considered least acceptable.
Results of Sensory evaluation of toast which made from mixing different wheat flour 50\% with 50\% Egyptian wheat flour are shown in table 6. From the result it can be noticed that Australian and Argentine toast had highest total scores 83.4 and $84.8 \%$ respectively than all among of toast and the Egyptian toast $100 \%$ (control) 80.6\% while American toast had the lowest total scores $68.4 \%$. Highest mean score for crust colour (7.6) was obtained by 
Australian toast whereas Germany and American toast got the lowest score (6.4). The low score of Germany and American toast may be due to high ash content, which affect the crust colour of bread since consumers prefer creamy colour and not dark brown bread. In case of appearance, Argentine toast bread was at the top (18.2) followed by Australian toast (18.0) and found to be least (14.4) for American toast. Maximum aroma score (7.4) was attained by Argentine toast while American toast received the minimum score (4.8). For crumb texture, highest mean score (15.8) was obtained by Australian and Argentine toast followed by Germany and Ukrainian toast (15.6). As regards eating quality, Australian toast got the maximum score (18.2) and American toast obtained the minimum score (14.2). American toast obtained the least score (15.2) for crumb grain whereas Australian and Argentine toast received the highest score (15.8). With respect to overall acceptability of bread, highest score (84.8) was obtained by Argentine toast and thus regarded as more acceptable than other wheat flour while lowest score (68.4) was obtained by American toast thus considered least acceptable.

Tables 4, 5 and 6 showed that the result of appearance, crumb, texture, crumb grain, crust colour, aroma, eating quality and total scores to evaluate sensory properties of toast bread which baking from pure flour $100 \%$ (control), mixing flour (25\% other flour + $75 \%$ Egyptian flour) and(50\% other flour $+50 \%$ Egyptian flour) from the ideal results in Table 4, 5 and 6, it can be noticed that Argentine and Australian toast bread had highest total scores in the three cases of flour and the mixing flour $(50 \%$ other flour $+50 \%$ Egyptian flour) is the best total scores than the pure flour $100 \%$ (control) and mixing flour (25\% other flour + 75\% Egyptian flour). This results are parley with the results obtained by Farooq., et al. [15] and Dhaliwal., et al. [16].

\begin{tabular}{|c|c|c|c|c|c|c|c|c|}
\hline \multicolumn{2}{|c|}{ Flour wheat } & $\begin{array}{c}\text { Appearance } \\
20\end{array}$ & $\begin{array}{l}\text { Crumb } \\
\text { texture } 20\end{array}$ & $\begin{array}{c}\text { Crumb } \\
\text { Grain } 20\end{array}$ & $\begin{array}{c}\text { Crust } \\
\text { colour } 10\end{array}$ & Aroma 10 & $\begin{array}{c}\text { Eating } \\
\text { quality20 }\end{array}$ & $\begin{array}{c}\text { Total scores } \\
100\end{array}$ \\
\hline \multirow[t]{5}{*}{$50 \%+50 \%$} & ArW & $18.2^{\mathrm{a}}$ & $18.0^{\mathrm{a}}$ & $15.8^{\mathrm{a}}$ & $7.4^{\mathrm{ab}}$ & $7.4^{\mathrm{a}}$ & $18.0^{\mathrm{ab}}$ & 84.8 \\
\hline & $\mathrm{GeW}$ & $15.6^{\mathrm{b}}$ & $14.6^{c}$ & $15.6^{\mathrm{a}}$ & $6.4^{\mathrm{b}}$ & $5.6^{\mathrm{b}}$ & $16.6^{\mathrm{bc}}$ & 74.4 \\
\hline & UkW & $15.2^{\mathrm{bc}}$ & $14.2^{\mathrm{c}}$ & $15.6^{\mathrm{a}}$ & $6.6^{\mathrm{ab}}$ & $5.2^{\mathrm{b}}$ & $15.6^{\mathrm{cd}}$ & 72.4 \\
\hline & $\mathrm{AmW}$ & $14.4^{\mathrm{c}}$ & $13.4^{\mathrm{d}}$ & $15.2^{\mathrm{a}}$ & $6.4^{\mathrm{b}}$ & $4.8^{\mathrm{b}}$ & $14.2^{\mathrm{d}}$ & 68.4 \\
\hline & $\mathrm{AuW}$ & $18.0^{\mathrm{a}}$ & $16.8^{\mathrm{b}}$ & $15.8^{\mathrm{a}}$ & $7.6^{\mathrm{a}}$ & $7.0^{\mathrm{a}}$ & $18.2^{\mathrm{a}}$ & 83.4 \\
\hline \multicolumn{2}{|l|}{ ESW 100\% } & $16.6^{\mathrm{ab}}$ & $16.2^{\mathrm{ab}}$ & $15.6^{\mathrm{ab}}$ & $7.2^{\mathrm{a}}$ & $7.2^{\mathrm{b}}$ & $17.8^{\mathrm{a}}$ & 80.6 \\
\hline
\end{tabular}

Table 6: Sensory evaluation of toast which made from mixing different wheat flour 50\% with 50\% Egyptian wheat flour.

ArW: Argentine Soft Red winter Wheat; GeW: Germany Soft Red Wheat; UkW: Ukrainian Hard Red Wheat; AmW: American Soft Red Winter Wheat; AuW: Australian Stander White Wheat; ESW: Egyptian soft White Wheat (gamaza 7).

\section{Balady bread}

Data of baking pure flour $100 \%$ (control) in table 7 showed that Egyptian balady bread had the golden yellow colour 50.0 while Australian and argentine balady bread had some browning with golden yellow colour 50.14 and 50.20 respectively. On the other hand the Germany balady bread had golden red colour 48.78 which is not good ability to panelists. Additionally the weight after baking for among of balady bread were ranged between 125 to $135 \mathrm{gm}$. Which the Ukrainian balady bread had heaviest weight 135gm followed by all among of balady bread 130gm while Australian balady bread had less weight $125 \mathrm{gm}$. In the other side the volume after baking is different because the Australian balady bread had a highest volume $883 \mathrm{~cm} 3$ followed by Argentine balady bread $644 \mathrm{~cm}^{3}$ while American balady bread had lowest volume $262 \mathrm{~cm}^{3}$, so the specific volume is related to the volume too because the Australian balady bread had highest volume $7.1 \mathrm{~cm}^{3} / \mathrm{g}$ followed by Argentine balady bread $4.95 \mathrm{~cm}^{3} / \mathrm{g}$ while American balady bread had lowest volume $2.02 \mathrm{~cm}^{3} / \mathrm{g}$, however loaf volume for Australian balady bread had lowest loaf volume $0.14 \mathrm{~g} / \mathrm{cm}^{3}$ and more air in side it, then followed by Argentine balady bread $0.20 \mathrm{~g} / \mathrm{cm}^{3}$ while American balady bread had highest loaf volume $0.50 \mathrm{~g} / \mathrm{cm}^{3}$ and less air in side it. Moreover data of baking mixing flour (75\% Egyptian flour and $25 \%$ other flour) showed that Argentine balady bread had the golden yellow colour 50.07 while American and Australian balady bread had some browning with golden yellow colour 50.5 and 50.1 respectively. In the other hand the Germany balady bread had golden red colour 49.39 which is not good ability to panelists. Additionally data showed that the weight after baking for among of balady bread were ranged between 120 to $125 \mathrm{gm}$. So Ukrainian and Australian balady bread had heaviest weight $125 \mathrm{gm}$ while all among of balady bread had less weight $120 \mathrm{gm}$, in the other side the volume after baking is different because the Argentine balady bread had highest volume $453 \mathrm{~cm}^{3}$ followed by Australian balady bread $425 \mathrm{~cm} 3$ while American balady bread had lowest volume $161 \mathrm{~cm}^{3}$ , so the specific volume is related to the volume too because the Argentine balady bread had highest volume $3.77 \mathrm{~cm} 3 / \mathrm{g}$ followed by Australian balady bread $3.40 \mathrm{~cm}^{3} / \mathrm{g}$ while American balady bread had lowest volume $1.43 \mathrm{~cm}^{3} / \mathrm{g}$, however loaf volume for Argentine balady bread had lowest loaf volume $0.26 \mathrm{~g} / \mathrm{cm}^{3}$ and more air in side it, then followed by Australian balady bread $0.29 \mathrm{~g} / \mathrm{cm}^{3}$ while American balady bread had highest loaf volume $0.75 \mathrm{~g} / \mathrm{cm}^{3}$ and less air inside it. Moreover data of baking mixing flour (50\% Egyptian flour and $50 \%$ other flour) showed that Argentine balady bread had the golden yellow colour 50.1 while American and Australian balady bread had some browning with golden yellow colour 50.0 and 50.23 respectively. In other hand the Ukrainian balady bread had golden red colour 48.8 which is not good ability to panelists. Results presented in table 7 that the weight after baking for among of balady bread were ranged between 127 to 130 gm so Argentine balady bread had heaviest weight $130 \mathrm{gm}$ while Germany and 
Ukrainian balady bread had less weight 125 and $127 \mathrm{gm}$ respectively, in the other side the volume after baking is different because the Argentine balady bread had highest volume $575 \mathrm{~cm}^{3}$ followed by Australian balady bread $453 \mathrm{~cm}^{3}$ while American balady bread had lowest volume $245 \mathrm{~cm}^{3}$, so the specific volume is related to the volume too because the Argentine balady bread had highest volume $4.42 \mathrm{~cm}^{3} / \mathrm{g}$ followed by Australian balady bread $3.54 \mathrm{~cm}^{3} / \mathrm{g}$ while American balady bread had lowest volume $1.91 \mathrm{~cm}^{3} / \mathrm{g}$, however loaf volume for Argentine balady bread had lowest loaf volume $0.23 \mathrm{~g} / \mathrm{cm}^{3}$ and more air in side it, then followed by Australian balady bread $0.28 \mathrm{~g} / \mathrm{cm}^{3}$ while American balady bread had highest loaf volume $0.52 \mathrm{~g} / \mathrm{cm}^{3}$ and less air in side.

\section{Sensory evaluation}

Data in table 8 showed that the Sensory evaluation of Balady Bread made from different wheat flour (100\%). From the result in table 8 it can be noticed that Australian balady bread had highest total scores than the Egyptian and Argentine balady bread 79.0, 75.5 and $69.5 \%$ respectively until the lowest one is American balady bread $57.0 \%$. bread prepared from different wheat cultivars flour were subjected to sensory evaluation for crust colour, crust characteristic, crumb colour, taste and flavour, grain and texture and chewing each their mean scores were calculated (Table 8). Highest mean score for crust colour (8.0) was obtained by Egyp-

\begin{tabular}{|c|c|c|c|c|c|c|c|}
\hline \multirow{2}{*}{\multicolumn{2}{|c|}{ wheat Flour }} & \multicolumn{2}{|c|}{ Crust colour } & \multirow{3}{*}{$\begin{array}{c}\begin{array}{c}\text { Weight after } \\
\text { baking gm }\end{array} \\
130.0\end{array}$} & \multirow{3}{*}{$\begin{array}{c}\text { Volume after } \\
\text { baking }\end{array}$} & \multirow{3}{*}{$\begin{array}{c}\text { Specific volume } \\
\mathbf{c m} 3 / \mathbf{g}\end{array}$} & \multirow{3}{*}{$\begin{array}{c}\begin{array}{c}\text { Loaf volume } \\
\text { g/cm3 }\end{array} \\
0.20 \\
\end{array}$} \\
\hline & & \multirow{2}{*}{$\begin{array}{l}\text { White } \\
-27.50\end{array}$} & \multirow{2}{*}{$\begin{array}{c}\text { yellow } \\
50.20 \\
\end{array}$} & & & & \\
\hline Control 100\% & ArW & & & & & & \\
\hline & $\mathrm{GeW}$ & -25.68 & 48.78 & 130.0 & 349 & 2.68 & 0.37 \\
\hline & UkW & -26.72 & 49.78 & 135.0 & 303 & 2.24 & 0.45 \\
\hline & AmW & -21.82 & 51.00 & 130.0 & 262 & 2.02 & 0.50 \\
\hline & $\mathrm{AuW}$ & -30.66 & 50.14 & 125.0 & 883 & 7.10 & 0.14 \\
\hline & ESW & -30.88 & 50.00 & 130.0 & 453 & 3.48 & 0.28 \\
\hline $25 \%+75 \%$ & ArW & -30.61 & 50.07 & 120.0 & 453 & 3.77 & 0.26 \\
\hline & GeW & 26.39 & 49.39 & 120.0 & 312 & 2.60 & 0.38 \\
\hline & UkW & -26.90 & 49.89 & 125.0 & 191 & 1.53 & 0.65 \\
\hline & AmW & -30.66 & 50.15 & 120.0 & 161 & 1.34 & 0.75 \\
\hline & $\mathrm{AuW}$ & 30.63 & 50.10 & 125.0 & 425 & 3.40 & 0.29 \\
\hline $50 \%+50 \%$ & ArW & -30.63 & 50.10 & 130.0 & 575 & 4.42 & 0.23 \\
\hline & GeW & -26.26 & 49.50 & 125.0 & 349 & 2.79 & 0.35 \\
\hline & UkW & -25.84 & 48.80 & 127.0 & 247 & 1.94 & 0.51 \\
\hline & AmW & -21.80 & 51.00 & 128.0 & 245 & 1.91 & 0.52 \\
\hline & $\mathrm{AuW}$ & -30.71 & 50.23 & 128.0 & 453 & 3.54 & 0.28 \\
\hline
\end{tabular}

Table 7: Physical properties of Balady Bread made from different wheat flour (100\%) and mixing by 75 and $50 \%$ with Egyptian wheat flour.

ArW: Argentine Soft Red winter Wheat; GeW: Germany Soft Red Wheat; UkW: Ukrainian Hard Red Wheat; AmW: American Soft Red Winter Wheat; AuW: Australian Stander White Wheat; ESW: Egyptian soft White Wheat (gamaza 7).

\begin{tabular}{|c|c|c|c|c|c|c|c|c|}
\hline \multicolumn{2}{|c|}{ wheat Flour } & $\begin{array}{l}\text { Crust } \\
\text { colour } 10\end{array}$ & $\begin{array}{c}\text { Crust } \\
\text { characteristics } 10\end{array}$ & $\begin{array}{l}\text { Crumb } \\
\text { colour } 20\end{array}$ & $\begin{array}{l}\text { Grain and } \\
\text { texture } 20\end{array}$ & $\begin{array}{l}\text { Taste and } \\
\text { flavor } 20\end{array}$ & Chewing 20 & $\begin{array}{c}\text { Total } \\
\text { scores } 100\end{array}$ \\
\hline \multirow[t]{6}{*}{ Control $100 \%$} & \multirow{6}{*}{$\begin{array}{l}\text { ArW } \\
\text { GeW } \\
\text { UkW } \\
\text { AmW } \\
\text { AuW } \\
\text { ESW }\end{array}$} & $6.5^{\mathrm{ab}}$ & $7.0^{\mathrm{a}}$ & $15.0^{\mathrm{ab}}$ & $13.0^{\mathrm{a}}$ & $14.0^{\mathrm{a}}$ & $14.0^{\mathrm{a}}$ & 69.5 \\
\hline & & $6.5^{\mathrm{ab}}$ & $6.5^{\mathrm{a}}$ & $12.0^{\mathrm{ab}}$ & $14.0^{\mathrm{a}}$ & $13.0^{\mathrm{a}}$ & $12.0^{\mathrm{a}}$ & 64.0 \\
\hline & & $5.0^{\mathrm{b}}$ & $6.5^{\mathrm{a}}$ & $11.0^{\mathrm{ab}}$ & $14.0^{\mathrm{a}}$ & $13.0^{\mathrm{a}}$ & $13.0^{\mathrm{a}}$ & 62.5 \\
\hline & & $5.5^{\mathrm{b}}$ & $6.5^{\mathrm{a}}$ & $10.0^{\mathrm{b}}$ & $11.0^{\mathrm{a}}$ & $12.0^{\mathrm{a}}$ & $12.0^{\mathrm{a}}$ & 57.0 \\
\hline & & $8.0^{\mathrm{a}}$ & $8.0^{\mathrm{a}}$ & $16.0^{\mathrm{a}}$ & $16.0^{\mathrm{a}}$ & $15.0^{\mathrm{a}}$ & $16.0^{\mathrm{a}}$ & 79.0 \\
\hline & & $8.0^{\mathrm{a}}$ & $7.5^{\mathrm{a}}$ & $16.0^{\mathrm{a}}$ & $15.0^{\mathrm{a}}$ & $14.0^{\mathrm{a}}$ & $15.0^{\mathrm{a}}$ & 75.5 \\
\hline
\end{tabular}

Table 8: Sensory evaluation of Balady Bread made from different wheat flour (100\%).

ArW: Argentine Soft Red winter Wheat; GeW: Germany Soft Red Wheat; UkW: Ukrainian Hard Red Wheat; AmW: American Soft Red Winter Wheat; AuW: Australian Stander White Wheat; ESW: Egyptian soft White Wheat (gamaza 7). 
tian and Australian balady bread whereas Ukrainian balady bread got the lowest score (5.0). The low score of Ukrainian balady bread may be due to high fiber and ash content, which affect the colour of bread since consumers prefer creamy colour and not dark brown bread. In case of taste and flovour, Australian balady bread was at the top (15.0) followed by Egyptian and Argentine balady bread (14.0) and found to be least (12.47) for American balady bread. Maximum crust characteristic score (8.0) was attained by Australian balady bread while Ukrainian, American and Germany balady bread received the minimum score (6.50). American balady bread obtained the least score (10.0) for crumb colour whereas Egyptian and Australian balady bread received the highest score (16.0). The differences in colour, taste and flavour of all the bread were attributed to the differences in hardness/softness of wheat grains and other factors like wheat varieties and milling characteristics of wheat. For grain and texture, highest mean score (16.0) was obtained by Australian balady bread followed by Egyptian balady bread (15.0). As regards chewing, Australian balady bread got the maximum score (16.0) and American and Germany balady bread obtained the minimum score (12.0). A wheaty aroma and taste is desirable with a non sticky, soft chewing feel in mouth. With respect to overall acceptability of chapattis, highest score (79.0) was obtained by Australian balady bread and thus regarded as more acceptable than other wheat flour while lowest score (57.0) was obtained by American balady bread thus considered least acceptable. This results are parley with the results obtained by Farooq., et al. [15] and Dhaliwal., et al. [16].

Data of table 9 evaluated sensory properties of balady bread which making from $25 \%$ other flour with $75 \%$ Egyptian flour. from the result it can be noticed that Australian and argentine balady bread had highest total scores 61.0 and $60.0 \%$ respectively and less than the Egyptian balady bread $100 \%$ (control) $75.5 \%$ while American balady bread had the lowest total scores $46.5 \%$. bread prepared from different wheat varieties flour were subjected to sensory evaluation for crust colour, crust characteristic, crumb colour, taste and flavour, grain and texture and chewing each their mean scores were calculated (Table 9). Highest mean score for crust colour (6.5) was obtained by Australian balady bread whereas American balady bread got the lowest score (5.0). The low score of American balady bread may be due to high ash content, which affect the colour of bread since consumers prefer creamy colour and not dark brown bread. In case of taste and flovour, Argentine and Germany balady bread was at the top (12.0) followed by American, Ukrainian and Australian balady bread (10.0). Maximum crust characteristic score (6.5) was attained by Australian balady bread while American balady bread received the minimum score (4.50). American balady bread obtained the least score (9.0) for crumb colour whereas Argentine balady bread received the highest score (12.0). For grain and texture, highest mean score (14.0) was obtained by Australian balady bread followed by Argentine balady bread (13.0). As regards chewing, Australian and Argentine balady bread got the maximum score (13.0) and American balady bread obtained the minimum score (10.0). With respect to overall acceptability of chapattis, highest score (61.0) was obtained by Australian balady bread and thus regarded as more acceptable than other wheat flour while lowest score (46.5) was obtained by American balady bread thus considered least acceptable.

Data of table 10 evaluated sensory properties of balady bread which baking from $50 \%$ other flour with 50\% Egyptian flour. from the result it can be noticed that Australian balady bread had highest total scores 85.1 than American balady bread had the lowest total scores $57.0 \%$. and the Australian balady bread was highest than Egyptian balady bread $100 \%$ (control) $75.5 \%$. bread prepared from different wheat varieties flour were subjected to sensory evaluation for crust colour, crust characteristic, crumb colour, taste and flavour, grain and texture and chewing each their mean scores were calculated (Table 10). Highest mean score for crust colour (9.2) was obtained by Australian balady bread whereas American balady bread got the lowest score (5.0). The low score of American balady bread may be due to high ash content, which affect the colour of bread since consumers prefer creamy colour and not dark brown bread. In case of taste and flovour, Australian and Argentine balady bread was at the top (16.0) followed by Ukrainian balady bread (13.0) and found to be least (12.0) for American and Germany balady bread. Maximum crust characteristic score (8.5) was attained by Australian balady bread while American balady bread received the minimum score (5.0). American balady bread obtained the least score (11.0) for crumb colour whereas Australian balady bread received the highest score (18.4). For grain and texture, highest mean score (16.0) was obtained by Australian balady bread followed by Argentine, Germany and Ukrainian balady bread (13.0). As regards chewing, Australian balady bread got the maximum score (17.0)

\begin{tabular}{|c|c|c|c|c|c|c|c|c|}
\hline \multicolumn{2}{|c|}{ Wheat Flour } & $\begin{array}{c}\text { Crust colour } \\
10\end{array}$ & $\begin{array}{c}\text { Crust } \\
\text { characteristics } 10\end{array}$ & $\begin{array}{l}\text { Crumb } \\
\text { colour } 20\end{array}$ & $\begin{array}{l}\text { Grain and } \\
\text { texture } 20\end{array}$ & $\begin{array}{l}\text { Taste and } \\
\text { flavor } 20\end{array}$ & $\begin{array}{c}\text { Chewing } \\
20\end{array}$ & $\begin{array}{c}\text { Total } \\
\text { scores } 100\end{array}$ \\
\hline \multirow[t]{5}{*}{$25 \%+75 \%$} & \multirow{5}{*}{$\begin{array}{l}\text { ArW } \\
\text { GeW } \\
\text { UkW } \\
\text { AmW } \\
\text { AuW }\end{array}$} & $5.5^{\mathrm{a}}$ & $5.0^{\mathrm{a}}$ & $12.0^{\mathrm{a}}$ & $13.0^{\mathrm{ab}}$ & $12.0^{\mathrm{a}}$ & $13.0^{\mathrm{a}}$ & 60.5 \\
\hline & & $6.0^{\mathrm{a}}$ & $6.0^{\mathrm{a}}$ & $11.0^{\mathrm{a}}$ & $10.0^{\mathrm{ab}}$ & $12.0^{\mathrm{a}}$ & $12.0^{\mathrm{a}}$ & 57.0 \\
\hline & & $6.0^{\mathrm{a}}$ & $5.0^{\mathrm{a}}$ & $10.0^{\mathrm{a}}$ & $12.0^{\mathrm{ab}}$ & $10.0^{\mathrm{a}}$ & $12.0^{\mathrm{a}}$ & 55.0 \\
\hline & & $5.0^{\mathrm{a}}$ & $4.5^{\mathrm{a}}$ & $9.0^{\mathrm{a}}$ & $8.0^{b}$ & $10.0^{\mathrm{a}}$ & $10.0^{\mathrm{a}}$ & 46.5 \\
\hline & & $6.5^{\mathrm{a}}$ & $6.5^{\mathrm{a}}$ & $11.0^{\mathrm{a}}$ & $14.0^{\mathrm{a}}$ & $10.0^{\mathrm{a}}$ & $13.0^{\mathrm{a}}$ & 61.0 \\
\hline \multicolumn{2}{|l|}{ ESW 100\% } & $8.0^{\mathrm{a}}$ & $7.5^{\mathrm{a}}$ & $16.0^{\mathrm{a}}$ & $15.0^{\mathrm{a}}$ & $14.0^{\mathrm{a}}$ & $15.0^{\mathrm{a}}$ & 75.5 \\
\hline
\end{tabular}

Table 9: Sensory evaluation of balady bread which made from mixing different wheat flour 25\%and 75\% with Egyptian wheat flour. ArW: Argentine Soft Red winter Wheat; GeW: Germany Soft Red Wheat; UkW: Ukrainian Hard Red Wheat; AmW: American Soft Red Winter Wheat; AuW: Australian Stander White Wheat; ESW: Egyptian soft White Wheat (gamaza 7). 


\begin{tabular}{|c|c|c|c|c|c|c|c|c|}
\hline \multicolumn{2}{|c|}{ Wheat Flour } & $\begin{array}{l}\text { Crust } \\
\text { colour } 10\end{array}$ & $\begin{array}{c}\text { Crust } \\
\text { characteristics } 10\end{array}$ & $\begin{array}{l}\text { Crumb } \\
\text { colour } 20\end{array}$ & $\begin{array}{c}\text { Grain and } \\
\text { texture } 20\end{array}$ & $\begin{array}{l}\text { Taste and } \\
\text { flavor } 20\end{array}$ & Chewing 20 & $\begin{array}{c}\text { Total scores } \\
\mathbf{1 0 0}\end{array}$ \\
\hline \multirow[t]{5}{*}{$50 \%+50 \%$} & ArW & $6.5^{\mathrm{bc}}$ & $8.0^{\mathrm{a}}$ & $14.8^{\mathrm{ab}}$ & $13.0^{\mathrm{a}}$ & $16.0^{\mathrm{a}}$ & $12.0^{\mathrm{b}}$ & 70.3 \\
\hline & GeW & $7.5^{\mathrm{ab}}$ & $8.0^{\mathrm{a}}$ & $13.0^{\mathrm{b}}$ & $13.0^{\mathrm{a}}$ & $12.0^{\mathrm{a}}$ & $14.8^{\mathrm{ab}}$ & 68.3 \\
\hline & UkW & $7.5^{\mathrm{ab}}$ & $7.0^{\mathrm{ab}}$ & $13.0^{\mathrm{b}}$ & $13.0^{\mathrm{a}}$ & $13.0^{\mathrm{a}}$ & $12.0^{\mathrm{b}}$ & 65.5 \\
\hline & AmW & $5.0^{c}$ & $5.0^{\mathrm{b}}$ & $11.0^{\mathrm{b}}$ & $12.0^{\mathrm{a}}$ & $12.0^{\mathrm{a}}$ & $12.0^{\mathrm{b}}$ & 57.0 \\
\hline & AuW & $9.2^{\mathrm{a}}$ & $8.5^{\mathrm{a}}$ & $18.4^{\mathrm{a}}$ & $16.0^{\mathrm{a}}$ & $16.0^{\mathrm{a}}$ & $17.0^{\mathrm{a}}$ & 85.1 \\
\hline \multicolumn{2}{|l|}{ ESW 100\% } & $8.0^{\mathrm{a}}$ & $7.5^{\mathrm{a}}$ & $16.0^{\mathrm{a}}$ & $15.0^{\mathrm{a}}$ & $14.0^{\mathrm{a}}$ & $15.0^{\mathrm{a}}$ & 75.5 \\
\hline
\end{tabular}

Table 10: Sensory evaluation of balady bread which made from mixing different wheat flour $50 \%$ and $50 \%$ with Egyptian wheat flour. ArW: Argentine Soft Red winter Wheat; GeW: Germany Soft Red Wheat; UkW: Ukrainian Hard Red Wheat; AmW: American Soft Red Winter Wheat; AuW: Australian Stander White Wheat; ESW: Egyptian soft White Wheat (gamaza 7).

and American, Argentine and Ukrainian balady bread obtained the minimum score (12.0). With respect to overall acceptability of chapattis, highest score (85.1) was obtained by Australian balady bread and thus regarded as more acceptable than other wheat flour while lowest score (57.0) was obtained by American balady bread thus considered least acceptable.

Tables 8,9 and 10 showed that the result of crust colour, crust characteristic, crumb colour, grain and texture, taste and flavor, chewing and total scores to evaluate sensory properties of balady bread which baking from pure flour $100 \%$ (control), mixing flour (25\% other flour $+75 \%$ Egyptian flour) and $(50 \%$ other flour + $50 \%$ Egyptian flour) from the result it can be noticed that Argentine and Australian balady bread had highest total scores in the three cases of flour and the mixing flour (50\% other flour $+50 \%$ Egyptian flour) is the best total scores than the pure flour $100 \%$ (control) and mixing flour (25\% other flour $+75 \%$ Egyptian flour). This results are agreement with the results obtained by Rabie [17].

\section{Conclusion}

Data indicated that Australian and Argentine, flours had more suitable properties for bread- making than the American and Egyptian flours. From the different tested wheat flours indicated that those made from Australian wheat, and Argentine wheat flours were superior.

\section{Bibliography}

1. Peressini D., et al. "Improvement of wheat fresh pasta-making quality: influence of sodium chloride on dough rheological properties". Italian Food and Beverage Technology 17 (1999): 20-23,33.

2. FAO. "Food and Agriculture Organization". FAO Statistics Database (2005).

3. Franklin Peter S. Bread, Encyclopedia of Food and Culture, Hand Book (2003).

4. Shah SIH., et al. "Physico-chemical qualities and nutritional attributes of stable bread wheat varieties representing diverse genetic origins". Sindh University Journals 40 (2008): 1-4.
5. Katarina V., et al. "Effects of mill stream flours technological quality on fermentative activity of baker's yeast Saccharomyces cerevisiae". University of Novi Sad, Faculty of Technology, Original scientific paper BIBLID: 1450-7188, 39 (2008): 153159

6. Schuler SF., et al. "Relationship of test weight and kernel properties to milling and baking quality in soft red winter wheat". Crop Science 35 (1995): 949.

7. Grausgruber H., et al. "Stability of quality traits in Austriangrown winter wheats". Field Crop Research 66 (2000): 257267.

8. TIAN Ji-chun., et al. "The Variation and Stability Analysis of Wheat Dough Stability Time". Agricultural Sciences in China 6.2 (2007): 143-149.

9. U.S. Department of Agriculture. GRAIN INSPECTION HANDBOOK I. Grain Inspection, Packers and Stockyards Administration, Federal Grain Inspection Service Probe Sampling, Washington, D.C. (1995 A): 20090-6454.

10. U.S. Department of Agriculture. MOISTURE HANDBOOK Grain Inspection, Packers and Stockyards Administration 1400 Independence Ave., S. W. Washington, D.C. (1999 B): 20250-3600

11. U.S. Department of Agriculture. EQUIPMENT HANDBOOK. Grain Inspection, Packers and Stockyards Administration,1400 Independence Ave., S.W. Washington, D.C. (2002 C): 20250-3600.

12. AACC. American association of cereal chemists, Aproved method of the AACC 10th ed., AACC, St Paul, MN 11 (2000 A).

13. Rashed MM., et al. "Effect of wheat flour and yeast on balady bread characterisitics. Egypt". Journal of Food Science 24 (1996): 81-92.

14. SAS. SAS/Stat. User's Guide: statistics, system for windows, version 4.10 (releasa 6.12 TS level 0020), SAS Inst., Inc. Cary, North Carolina, USA (1999). 
Effect of Handling, Milling Process and Storage on the Quality of Wheat and Flour in Egypt: [3] Sensory Evaluation for Bread Making from Different Wheat Flours

15. Farooq Z., et al. "Suitability of wheat varieties/lines for the production of leavened flat bread(naan)". Journal of Research in Science 12 (2001): 171-179.

16. Dhaliwal YS., et al. "Methodology for preparation and testing of chapattis produced from different classes of Canadian wheat". Food Research International 29 (1996): 163-168.

17. Rabie Samir Mohamed Hussein. Soft wheat quality factors that influence the quality characteristics of Egyptian Balady bread, Ph.D., Theses Michigan State University (1992).

Volume 3 Issue 10 October 2019

(C) All rights are reserved by El-Sisy TT., et al. 